\title{
The Effects of Using Pomegranate (Punica granatum) Seed Powder on Quality Parameters of Model System Chicken Meat Emulsions
}

\author{
Meltem Serdaroğlu' ${ }^{1, a, *}$, Özlem Yüncü̈ ${ }^{1, b}$, Hülya Serpil Kavuşan ${ }^{1, c}$, \\ Elnaz Sharefiabadi ${ }^{1, d}$, Sahar Seyedhosseini ${ }^{1, e}$ \\ ${ }^{1}$ Food Engineering Department, Engineering Faculty, Ege University, 35100, Bornova/İmir, Turkey
} *Corresponding author

\begin{tabular}{l|l}
\hline A R T I C L E I N F O & A B S T R A C T \\
\hline $\begin{array}{l}\text { Research Article } \\
\text { Received : 12/03/2021 }\end{array}$ & $\begin{array}{l}\text { This study aimed to investigate the effects of using 1\%, 3\% and 5\% pomegranate seed powder (PSP) } \\
\text { on model system chicken meat emulsion (CME) quality parameters. For this purpose, the properties } \\
\text { of the emulsion samples prepared using different amounts of PSP were compared with the control } \\
\text { group prepared with 70\% chicken breast meat, 18\% chicken skin, 10\% water, } 1.5 \% \text { salt and } 0.5 \% \\
\text { sodium tripolyphosphate (STPP). Chemical composition, pH, emulsion stability, water holding } \\
\text { capacity, cooking yield, and color were analyzed in emulsion samples. TBARs and peroxide values } \\
\text { of the samples were determined on days } 0,3,5 \text { and } 7 \text { during storage. Use of pomegranate seed powder } \\
\text { in emulsion formulation resulted a decrease in } b * \text { and } a * \text { values. At the same time, with the addition } \\
\text { of pomegranate seed powder, there was no difference in the protein values of the raw samples and } \\
\text { the moisture, ash and pH values of the cooked samples. It was also observed that pH values, water } \\
\text { holding capacity and cooking efficiency of emulsions increased with the increasing levels of PSP. } \\
\text { Both peroxide and TBARs values were lower in emulsion samples formulated with PSP on } 7 \mathrm{~d} \\
\text { compared to the control group. }\end{array}$ \\
$\begin{array}{l}\text { Keywords: } \\
\text { Antioxidant } \\
\text { Chicken meat emulsion } \\
\text { Pomegranate seed }\end{array}$ &
\end{tabular}

\section{Model Sistem Tavuk Eti Emülsiyonlarında Nar (Punica granatum) Çekirdeği Tozu Kullanımının Kalite Özellikleri Üzerine Etkileri}

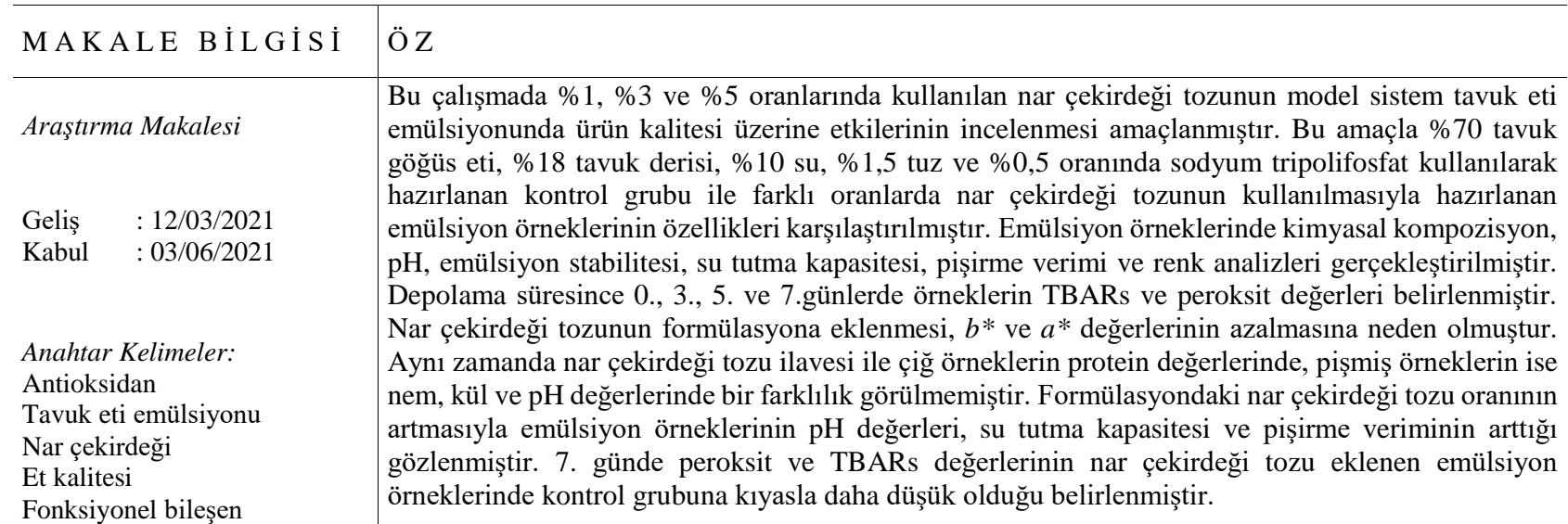

(iD) https://orcid.org/0000-0003-1589-971X (i) https://orcid.org/0000-0003-2928-8020 iD https://orcid.org/0000-0001-5059-1417 bozlemm_yuncu@hotmail.com (iD) https://orcid.org/0000-0002-9112-1427
$\begin{array}{ll}\text { d_sharefi@yahoo.com } & \text { (iD) https://orcid.org/0000-0002-4382-0469 }\end{array}$ el_sharefi@yahoo.com (iD) https://orcid.org/0000-0002-4382-0469 


\section{Introduction}

In recent years food consumption trends of consumers have been changed dramatically since they are aware of the strong relationship between diet and health. High dietary fiber, mineral, vitamin, and bioactive compounds intake can reduce the risk of cardiovascular diseases, stroke, hypertension, diabetes, obesity, and some gastrointestinal diseases (Anderson et al., 2009). Due to the high amounts of saturated fat, cholesterol and synthetic additives in their formulation meat products are particularly important in this regard. Therefore, the meat industry has been attempting to reformulate the products with healthier ingredients derived from natural sources. When all the aforementioned reasons take into consideration, it is obvious that the popularity of meat products with reduced fat and sodium contents, calories as well as enriched with functional ingredients such as dietary fibers has increased (Jimenez-Colmenero and Delgado-Pando, 2013). The overextending of meat products with plant sources (vegetables, fruits, seeds), and their fibers have the potential to increase the water-holding and fat binding capacities, reduces formulation costs, modifies the texture, improves storage stability, reduces cooking losses, and these sources have a neutral taste (Ekici and Ercoşkun, 2007; Sayago-Ayerdi et al., 2009; Petracci et al., 2013).

Apple pulp (Verma et al., 2010), bambara groundnut flour (Alakali et al., 2010), tomato (Cava et al., 2012), carrot (Eim et al., 2008; Grossi et al., 2011), Cyperus rotundus L. rhizome powder (Eltilib et al., 2016), moringa seed flour (Al-Juhaimi et al., 2016), apricot pomace (Purma Adıbelli and Serdaroğlu, 2017), dried pumpkin pulp and seed (Serdaroğlu et al., 2018), pepper seed (Lee et al., 2019; Kim, 2020), cowpea seed powder (Ebrahiem et al., 2020) have been utilized as dietary fiber sources in the formulation of various meat products.

Pomegranate (Punica granatum) is from the Punicaceae family, originated in Iran, and is widely produced in Iran, India, America, Near, and the Far East countries. After the juice is squeezed, pomegranate fruit contains $67 \%$ pulp and $78 \%$ of the pulp consists of the peel and $22 \%$ of the seed (Baysal and Taştan, 2018). Pomegranate seed contains significant amounts of oil, protein, dietary fiber, phenolic substances, minerals, and vitamins. Pomegranate peel is a significant source of tannins, anthocyanins, and flavonoids. Gil et al. (2000) stated that pomegranate seed and peel are predominantly containing punicalagin and its isomers (2,3hexahydroxydiphenol-4,6-gallagylglucose) ellagitannins, small amounts of punikaline (4,6 gallagglucose), gallic acid, ellagic acid, and ellagic acid glycosides (hexicide, pentoside, rhamnoside). Pomegranate seed also contains punic acid, conjugated linoleic acid, linolenic acid, and oleic acid in composition (Okumuş, 2016). When the mineral content is examined, it is seen that the elements with the highest rate are phosphorus, calcium, magnesium, and potassium. Therefore, pomegranate by-products can find various applications such as functional food ingredients, food additives, nutraceuticals and supplements, and diets rich in phenolics, and can be used as a substrate to produce nutritionally valuable and biologically active ingredients (Jalal et al., 2018).
Various studies have been done on the effects of using pomegranate peel or rind in meat product formulations ( $\mathrm{Li}$ et al., 2006; Naveena et al., 2008; Devatkal et al., 2014; Turgut et al., 2017; Smaoui et al., 2019; Garrido-Cruz et al., 2020; Sharma and Yadav, 2020; Zago et al., 2020; Gullón et al., 2020). However, pomegranate seed powder was only used in chicken nuggets (Kaur et al., 2015), goat meatball (Devatkal and Naveena, 2010; Devatkal et al., 2010), and beef patties (Kurt, 2017).

The aforementioned researches showed that up to this date a few researchers have only implemented the enhancement of meat products with pomegranate seeds, thereby a limited number of studies are available. That's why, the goal of this research was to evaluate the effect of pomegranate seed powder on chemical composition, color, functional properties, and lipid oxidation of model system chicken meat emulsion. It is thought that the results obtained in the study will contribute to future research and shed light.

\section{Materials and methods}

\section{Materials}

Pomegranate seed powder (defatted, $0.25 \mu \mathrm{m}$ particle size, pH:5.91, $\left.L^{*}: 47.89, a^{*}: 8.32, b^{*}: 17.38\right)$ was supplied from Başak Tarım Ltd. Co. and stored at room temperature until used. Fresh boneless chicken breast muscles (Pectoralis major) and chicken skin were purchased from a local butcher just before the production without breaking the cold chain.

\section{Preparation of Model System Chicken Meat Emulsion}

Preparation of chicken meat emulsion (CME) was carried out carried out in duplicate according to Cofrades et al. (2008) with some modifications. The production steps of CME are presented in Figure 1. Four different batches were prepared by using $0 \%(\mathrm{C}), 1 \%(\mathrm{P} 1), 3 \%(\mathrm{P} 3)$, and $5 \%(\mathrm{P} 5) \mathrm{PSP}$, and the formulation CME is seen in Table 1. Chicken breast meat and chicken skin grounded through a grinder with a $3 \mathrm{~mm}$ plate. Minced meat was mixed for $60 \mathrm{~s}$. in Thermomix (Vorwerk, Wuppertal, Germany), then chicken skin, ice, $\mathrm{NaCl}$, STPP (sodium tripolyphosphate), PSP were added and emulsified at $2500 \mathrm{rpm}$ for $5 \mathrm{~min}$. more. The temperature of the emulsion was kept lower than $12^{\circ} \mathrm{C}$ during the processing to avoid emulsion breakage. Prepared emulsions were filled into tapped centrifuge tubes $(50 \mathrm{~mL})$, then were heated for $30 \mathrm{~min}$. at $70^{\circ} \mathrm{C}$ and followed by centrifugation for $1 \mathrm{~min}$. at $2500 \mathrm{rpm}$ to remove the air bubbles from the matrix. Heat-treated samples were cooled and stored for $7 \mathrm{~d}$ in polypropylene cases under refrigerator conditions $\left(+4^{\circ} \mathrm{C}\right)$.

The progress of lipid oxidation was examined on days $0,3,5$, and 7 during 7 -day storage in 3 replicates by monitoring peroxide value and TBARs analysis.

\section{Physicochemical Analyses Carried on PSP}

$\mathrm{pH}$ value of PSP was measured by a method stated by Lee et al. (2008). To determine the water absorption capacity (WAC), one gram of PSP was added with $15 \mathrm{~mL}$ of distilled water and kept 12 hours at $22^{\circ} \mathrm{C}$. Then, to remove excessive water from matrix, centrifugation is applied to the PSPdistilled water mixture at $15,000 \times \mathrm{g}$ for $15 \mathrm{~min}$. Lastly, the water absorbed by PSP was calculated. WAC was stated as $\mathrm{g}$ water/g sample (McConnell et al., 1974). 
Table 1. Formulation of model meat emulsions

\begin{tabular}{|c|c|c|c|c|c|c|}
\hline Treatments & $\begin{array}{c}\text { Chicken breast meat } \\
(\%)\end{array}$ & $\begin{array}{l}\text { Chicken skin } \\
(\%)\end{array}$ & $\begin{array}{c}\text { Pomegranate seed powder (PSP) } \\
(\%)\end{array}$ & $\begin{array}{l}\text { Ice } \\
(\%)\end{array}$ & $\begin{array}{l}\text { Salt } \\
(\%)\end{array}$ & $\begin{array}{c}\text { STPP } \\
(\%)\end{array}$ \\
\hline $\mathrm{C}$ & 70 & 18 & - & 10 & 1.5 & 0.5 \\
\hline P1 & 69 & 18 & 1 & 10 & 1.5 & 0.5 \\
\hline P3 & 67 & 18 & 3 & 10 & 1.5 & 0.5 \\
\hline P5 & 65 & 18 & 5 & 10 & 1.5 & 0.5 \\
\hline
\end{tabular}

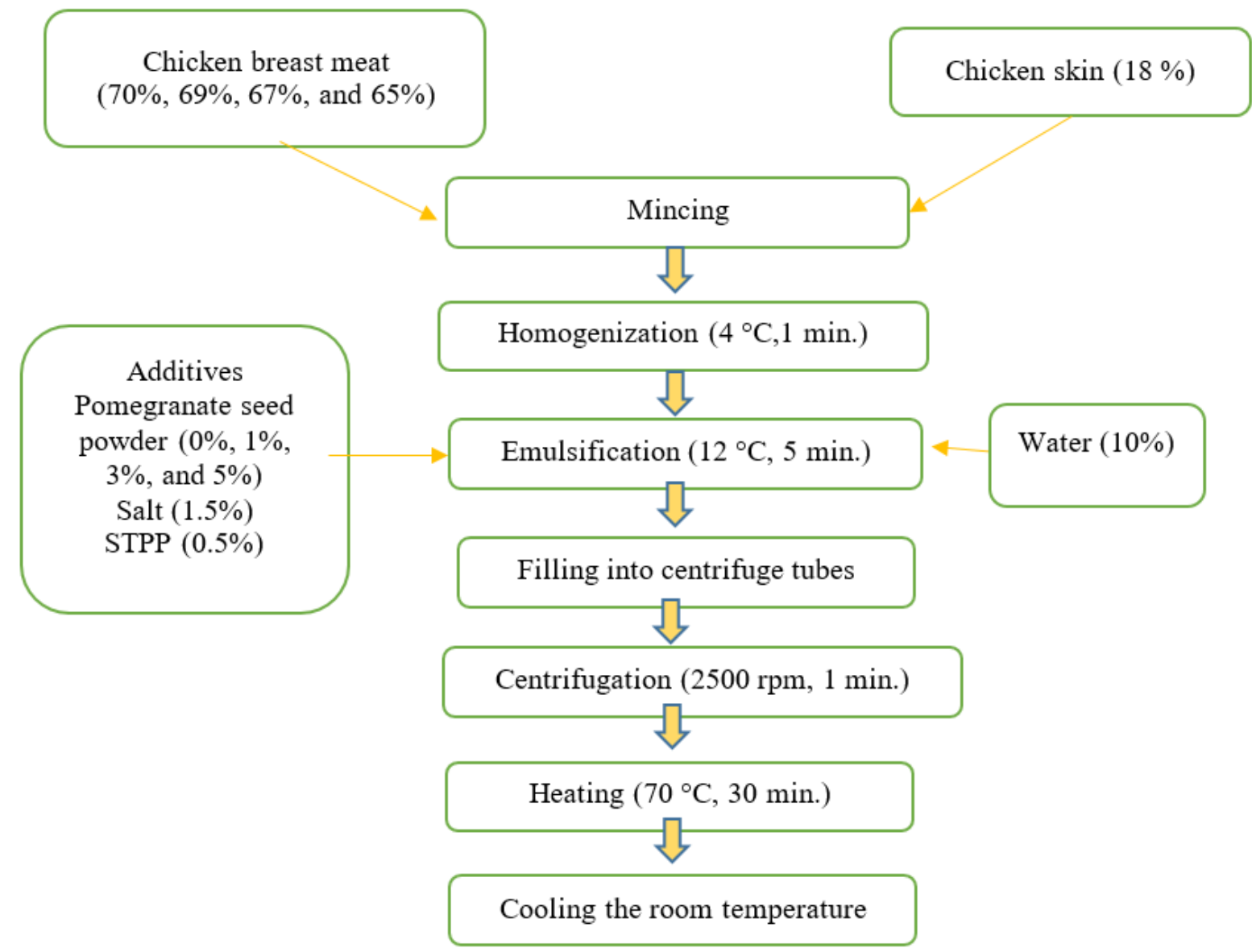

Figure 1. Production of model system chicken meat emulsions

The capacity of PSP to hold oil was specified by using a method of Lin et al. (1974) with modifications. One gram PSP was added with $10 \mathrm{~mL}$ sunflower oil and stirred with a vortex mixer for $30 \mathrm{~min}$., then centrifugation was carried out at $4^{\circ} \mathrm{C}$ for $10 \mathrm{~min}$. with $15,000 \mathrm{xg}$. The supernatant was detracted from mixture, and tube was turned round for 25 min. to evacuate the oil and the residue weighed $\left(\mathrm{W}_{\mathrm{r}}\right)$. Oil holding capacity $(\mathrm{OHC})$ was calculated by the equation given below.

$\mathrm{OHC}(\mathrm{g}$ oil $/ \mathrm{g}$ sample $)=\mathrm{W}_{\mathrm{r}} / \mathrm{W}_{\mathrm{i}}$

Where Wi was the sample weight $(\mathrm{g})$

\section{Emulsion Stability (ES)}

ES was calculated regarding the equation given below in terms of the total expressible fluid (TEF) and the expressible fat (EFAT). Twenty-five grams of chicken meat emulsion was centrifuged at $2,634 \times \mathrm{g}$ for one minute and heated in 30 minute in water bath at $70^{\circ} \mathrm{C}$. Later, emulsion samples were centrifuged again at $2,634 \times \mathrm{g}$ for 3 $\min$. The pellets were separated, and then the supernatants were dried (Hughes et al., 1997).

$$
\mathrm{TEF}=(\mathrm{WCT}+\mathrm{WS})-(\mathrm{WCT}+\mathrm{WP})
$$

WCT: Weight of centrifuge tube

WS : Weight of sample

WP : Weight of pellet

$$
\operatorname{TEF}(\%)=\frac{\mathrm{TEF}}{\mathrm{WS}} \times 100
$$

$$
\operatorname{EFAT}(\%)=\frac{(W C+W D S)-(W C T+W S)}{T E F} \times 100
$$

WC : Weight of crucible

WDS : weight of dried supernatant

WCT : Weight of centrifuge tube

WS : Weight of sample 


\section{Water Holding Capacity (WHC)}

The capacity of emulsion to hold the water was analyzed according to Hughes et al. (1997) with modifications. Ten grams of batter (W1) was put into a $90^{\circ} \mathrm{C}$ water bath for $10 \mathrm{~min}$. Subsequently, cooled samples surrounded with cotton gauze then centrifuged at $323 \times \mathrm{g}$ for $15 \mathrm{~min}$. The final weight (W2) of the samples was measured and the equation given below was used to calculate the water holding capacity.

$$
\text { WHC }(\%)=\left(1-\frac{\mathrm{W} 1-\mathrm{W} 2}{\mathrm{TMCS}}\right) \times 100
$$

TMCS: Total moisture content of sample

\section{Cooking Yield (CY)}

The cooking yield was counted from the weight alterations of the chicken meat emulsions previous and after the cooking process by using the equation below (Murphy et al., 1975):

$$
\text { Cooking yield }(\%)=\frac{\text { WCS }}{\text { WUS }} \times 100
$$

WCS : Weight of cooked sample

WUS : Weight of uncooked sample

\section{Chemical Composition}

Moisture (948.12; AOAC, 2007) and ash (945.46; AOAC 2007) contents were analyzed for total solids of cooked and uncooked samples. The fat content of the chicken meat emulsions was determined by using a method stated by Flynn and Bramblett (1975). An automatic nitrogen analyzer (FP 528, LECO, Michigan, USA) was used for measuring protein content according to Dumas method.

\section{pH}

The $\mathrm{pH}$ of chicken meat emulsions was measured by using a pH-meter ( $\mathrm{pH} 3110$ set 2, WTW, Weilheim, Germany) fitted out a drilling electrode.

\section{Peroxide Value (PV)}

The PV of the emulsion was analyzed by using titrimetric method according to Koniecko (1979). Titration was performed with $0.01 \mathrm{~N}$ sodium thiosulfate and results were calculated by using the equation below. Results are expressed as meq $\mathrm{O}_{2} / \mathrm{kg}$ chicken meat emulsion.

$$
\mathrm{PV}\left(\frac{\mathrm{mEqO}_{2}}{\mathrm{~kg}}\right)=\frac{\mathrm{S} \times \mathrm{N}}{\mathrm{WS}} \times 1000
$$

S : Volume of sodium thiosulfate used for titration

$\mathrm{N}$ : The normality sodium thiosulfate solution

WS : Weight of the sample

\section{Thiobarbituric Acid Reactive Substances (TBARs)}

TBARs was measured based on a method established by Witte et al. (1970) to measure the oxidation of lipids throughout storage time. Briefly, the method is aimed to measure the concentration of the malonaldehyde (MA) accumulated throughout the lipid oxidation reactions. MA reacts with 2- thiobarbituric acid at $80^{\circ} \mathrm{C}$ for $35 \mathrm{~min}$. and the amount of MA is determined spectrophotometrically at
$532 \mathrm{~nm}$ based on the intensity of resulted pink-colored compounds. 5.2 multiply the obtained absorbance value. Results are expressed as $\mathrm{mg}$ malonaldehyde/kg (mg $\mathrm{MA} / \mathrm{kg}$ ) chicken meat emulsion.

\section{Color}

A portable colorimeter (Chromameter CR400, Minolta, Tokyo, Japan) was used to obtain cross-sectional area colors of chicken meat emulsions. Color parameters measured according to CIELAB color system as CIE $L^{*}$, $a^{*}$, and $b^{*}$ means lightness, redness, and yellowness, respectively. Four repetitions were taken for each chicken meat emulsion group.

\section{Statistical Analyses}

Statistical analyses were applied by using SPSS program (IBM, version 21.0, USA). A one-way ANOVA was used to assess the effects of PSP ratio on the technological parameters such as ES, WHC, CY, chemical composition, $\mathrm{pH}$, and lipid oxidation (peroxide and TBARs) of chicken meat emulsion. To examine the effect of PSP and storage days on peroxide and TBARs, treatments (C, P1, P3, and P5) and storage days $(0,3,5$, and 7$)$ were assigned as fixed factors. Significant differences are examined by Duncan multiple tests at a $95 \%$ confidence level.

\section{Results and Discussion}

The results indicated that the $\mathrm{pH}$ of pomegranate seed powder was 5.9. Water absorption capacity refers to the ability of the material to absorb water when immersed in it. Water absorption capacity was $4.3 \mathrm{~g} / \mathrm{g}$ sample. Our result for water absorption capacity is similar to the findings of Jalal et al. (2018) who reported WHC of PSP as $4.45 \mathrm{~g} / \mathrm{g}$ sample. The oil holding capacity is a functional property linked to the chemical composition of the plant polysaccharides (Fernandez-Lopez et al., 2009). The oil holding capacity of PSP was $3.7 \mathrm{~g}$ oil $/ \mathrm{g}$ sample. It was seen that $\mathrm{OHC}$ value was found lower than a study $(5.81 \mathrm{~g} / \mathrm{g}$, Gölükcü et al., 2008). This finding is lower than the oil holding capacity of pomegranate bagasse $(5.9 \mathrm{~g}$ oil/g dry fiber, Viuda-Martos et al., 2012) and tiger nut by-product $(6.90 \mathrm{~g} \mathrm{oil} / \mathrm{g}$ fiber, Sanchez-Zapata et al., 2010). These differences could be due to the processing methods and hydrophobic nature of the fiber particle.

Technological Properties of Chicken Meat Emulsion

Functional properties of CME formulated with different levels of pomegranate seed powder (PSP) are presented in Table 2. WHC, which is the capability of meat to retain moisture is a significant quality indicator associated with ES (Öztürk et al., 2017). WHC values varied 70.43-74.08\%, PSP increased the WHC $(\mathrm{P}<0.05)$ regardless of the addition level. This situation could be elucidated by the high dietary fiber content of pomegranate seed samples. According to the findings of Gül and Şen (2017), pomegranate seed powder contains $52.22 \%$ of total dietary fiber on a dry matter. Jalal et al. (2018) reported that pomegranate seed powder has a water holding capacity of 4.45 times its weight and it has also been reported that the emulsifying capacity and emulsion stability of PSP is higher than the pomegranate peel powder. An important increase was observed in the crude fiber content of the products with the increase in the level of adding PSP and 
tomato powder to chicken nuggets (Kaur et al., 2015). In addition to the nutritional properties of fiber-enriched chicken nuggets, it was concluded that the ingredients added as dietary fiber could also be used for technological improvements such as improving rheological properties and texture in meat products. The $\mathrm{pH}$ and WHC values of uncooked samples increased with the addition of PSP $(\mathrm{P}<0.05)$. In parallel with the increase of $\mathrm{pH}$ of meat, load balance changes, the ripening degree of meat increases, it gains a tender structure, and its WHC improves (Anar, 2017).

The percent cooking yield of emulsion samples after heat treatment is seen in Table 2. The cooking efficiency of emulsion samples varies between $96.86 \%$ and $99.95 \%$, the addition of PSP significantly increased cooking yield $(\mathrm{P}<0.05)$. It has been well demonstrated that formulating meat products with ingredients that have high amounts of dietary fiber could increase cooking yield (Kurt, 2017; Kumar et al., 2019; Santhi et al., 2020). Our results were similar to the results of Al-Juhaimi et al. (2016) who also stated an increase in yield as well as WHC, fat, and moisture retention in beef burgers incorporated with moringa seed flour. It could be said that PSP increased protein -fat and water interaction and resulted in low water and fat release during the cooking process. Opposite to our findings, Kaur et al. (2015) reported that with the increase in the ratio of pomegranate seed powder added to chicken nuggets, there was a significant decrease in emulsion stability and cooking efficiency. This result was associated with a decrease in $\mathrm{pH}$ and hence in the water holding capacity. Pomegranate seed powder had no significant effect on the cooking yield of chicken patties (Kurt, 2017).

Emulsion stability is defined as the absence of phase separation in the emulsion and the resistance of its characteristics to change according to ambient conditions (Öztürk and Serdaroğlu, 2018). ES of the treatments in terms of TEF and EFAT is presented in Table 2. Utilization of PSP in the formulation resulted in a decrease in total expressible fluid and expressible fat $(\mathrm{P}<0.05)$. Such a decrease implies that PSP could contribute to the stabilization of chicken meat emulsion. This finding also could be explained by the oil holding capacity of PSP. Jalal et al. (2018) reported that PSP showed an oil holding capacity of $5.81 \mathrm{~g}$ oil $/ \mathrm{g}$ powder. Correspondingly with our results, beef patties added with pumpkin pulp and seed powder enhanced fat retention (Serdaroğlu et al., 2018). It was observed that the expressible amount of fluid and fat was the lowest in the samples formulated with PSP where water holding capacity and cooking efficiency were higher than control $(\mathrm{P}<0.05)$.

\section{Chemical Composition and $\mathrm{pH}$}

Compositional analysis of uncooked and cooked emulsion samples formulated with various amounts of PSP is seen in Table 3. The moisture, protein, fat, and ash contents of raw CME changed from $67.03 \%$ to $70.50 \%$, from $17.49 \%$ to $18.92 \%$, from $7.41 \%$ to $8.10 \%$, and from $2.55 \%$ to $2.84 \%$ respectively. No differences were obtained in protein content of uncooked samples with the addition of PSP, on the other hand, fat and ash contents decreased in comparison with the control group $(\mathrm{P}<0.05)$. Incorporating with PSP at levels of $3 \%$ and $5 \%$ decreased moisture content of emulsion samples. Debnath et al. (2020) and Ebrahiem et al. (2020) also recorded similar findings in cooked sausages. Moisture, protein, fat, and ash contents of cooked emulsions changed from $65.04 \%$ to $67.84 \%$, from $18.03 \%$ to $19.04 \%$, from $6.84 \%$ to $7.88 \%$, and from $2.06 \%$ to $2.82 \%$ respectively. With the use of $5 \%$ pomegranate seed powder in the formulation protein content increased while fat content decreased $(\mathrm{P}<0.05)$. The decrease in fat content could be explained by the addition of defatted PSP instead of chicken breast meat. No important differences were observed in the moisture and ash content of cooked emulsions $(\mathrm{P}>0.05)$. The use of moringa seed flour up to $6 \%$ in the beef burger formulation did not affect the chemical composition (Al-Juhaimi et al., 2016).

As shown in Table 3 increasing amounts of PSP increased $\mathrm{pH}$ values of uncooked samples $(\mathrm{P}<0.05)$. The high $\mathrm{pH}$ value (6.5) of PSP can be the reason for a slight increase in the $\mathrm{pH}$ values by the addition of PSP. Nevertheless, the addition of PSP did not change the $\mathrm{pH}$ of cooked emulsions, $\mathrm{pH}$ values are consistent with others reported for sausage emulsions (Eltilib et al., 2016; Lee et al., 2019), chicken loaves (Sajad et al., 2020), and chicken patties (Sharma and Yadav, 2020).

Table 2. Functional properties of model meat emulsion formulated with PSP

\begin{tabular}{l|cccc}
\hline Treatments & $\begin{array}{c}\text { Water holding capacity } \\
(\%)\end{array}$ & $\begin{array}{c}\text { Cooking yield } \\
(\%)\end{array}$ & $\begin{array}{c}\text { Total expressible fluid } \\
(\%)\end{array}$ & $\begin{array}{c}\text { Total expressible fat } \\
(\%)\end{array}$ \\
\hline C & $70.43 \pm 1.44^{\mathrm{b}}$ & $96.86 \pm 0.37^{\mathrm{c}}$ & $5.12 \pm 0.52^{\mathrm{a}}$ & $6.86 \pm 1.81^{\mathrm{a}}$ \\
P1 & $73.01 \pm 0.64^{\mathrm{a}}$ & $97.42 \pm 0.34^{\mathrm{b}}$ & $3.83 \pm 0.24^{\mathrm{b}}$ & $3.86 \pm 1.61^{\mathrm{b}}$ \\
P3 & $74.08 \pm 0.36^{\mathrm{a}}$ & $99.95 \pm 0.03^{\mathrm{a}}$ & $3.61 \pm 0.77^{\mathrm{b}}$ & $3.64 \pm 0.39^{\mathrm{b}}$ \\
P5 & $73.30 \pm 0.51^{\mathrm{a}}$ & $99.81 \pm 0.17^{\mathrm{a}}$ & $3.52 \pm 0.15^{\mathrm{b}}$ & $1.69 \pm 0.39^{\mathrm{b}}$ \\
\hline
\end{tabular}

Mean values \pm standard deviation, ${ }^{\text {a-c }}$ : different letters in the same column means significant differences $(\mathrm{P}<0.05)$.

Table 3. Chemical composition and $\mathrm{pH}$ value of model meat emulsions formulated with PSP

\begin{tabular}{|c|c|c|c|c|c|c|}
\hline \multicolumn{2}{|c|}{ Treatments } & Moisture (\%) & Protein $(\%)$ & Fat $(\%)$ & $\operatorname{Ash}(\%)$ & $\mathrm{pH}$ \\
\hline \multirow{4}{*}{ Uncooked } & $\mathrm{C}$ & $70.50 \pm 1.30^{\mathrm{a}}$ & $17.49 \pm 0.76$ & $8.10 \pm 0.24^{\mathrm{a}}$ & $2.84 \pm 0.04^{\mathrm{a}}$ & $6.26 \pm 0.01^{\mathrm{d}}$ \\
\hline & $\mathrm{P} 1$ & $69.61 \pm 0.82^{\mathrm{a}}$ & $17.83 \pm 1.23$ & $7.70 \pm 0.10^{\mathrm{b}}$ & $2.73 \pm 0.06^{\mathrm{ab}}$ & $6.31 \pm 0.01^{\mathrm{c}}$ \\
\hline & P3 & $67.82 \pm 0.51^{b}$ & $18.58 \pm 0.38$ & $7.44 \pm 0.05^{\mathrm{b}}$ & $2.55 \pm 0.15^{\mathrm{c}}$ & $6.55 \pm 0.03^{\mathrm{a}}$ \\
\hline & P5 & $67.03 \pm 0.23^{\mathrm{b}}$ & $18.92 \pm 0.12$ & $7.41 \pm 0.21^{b}$ & $2.66 \pm 0.02^{b c}$ & $6.44 \pm 0.01^{\mathrm{b}}$ \\
\hline \multirow{4}{*}{ Cooked } & $\mathrm{C}$ & $67.84 \pm 1.92$ & $18.03 \pm 0.36^{\mathrm{c}}$ & $7.88 \pm 0.08^{a}$ & $2.79 \pm 0.00$ & $6.43 \pm 0.06$ \\
\hline & $\mathrm{P} 1$ & $66.97 \pm 1.49$ & $18.54 \pm 0.34^{\mathrm{b}}$ & $7.39 \pm 0.36^{\mathrm{ab}}$ & $2.82 \pm 0.06$ & $6.43 \pm 0.06$ \\
\hline & P3 & $66.48 \pm 0.08$ & $18.27 \pm 0.05^{\mathrm{bc}}$ & $6.95 \pm 0.51^{\mathrm{ab}}$ & $2.06 \pm 0.46$ & $6.50 \pm 0.01$ \\
\hline & P5 & $65.04 \pm 0.75$ & $19.04 \pm 0.06^{\mathrm{a}}$ & $6.84 \pm 0.71^{\mathrm{b}}$ & $2.30 \pm 1.52$ & $6.43 \pm 0.01$ \\
\hline
\end{tabular}

Mean values \pm standard deviation, ${ }^{\text {a-c }}$ : different letters in the same column means significant differences $(\mathrm{P}<0.05)$. 
Peroxide value $(\mathrm{meqO} 2 / \mathrm{kg})$

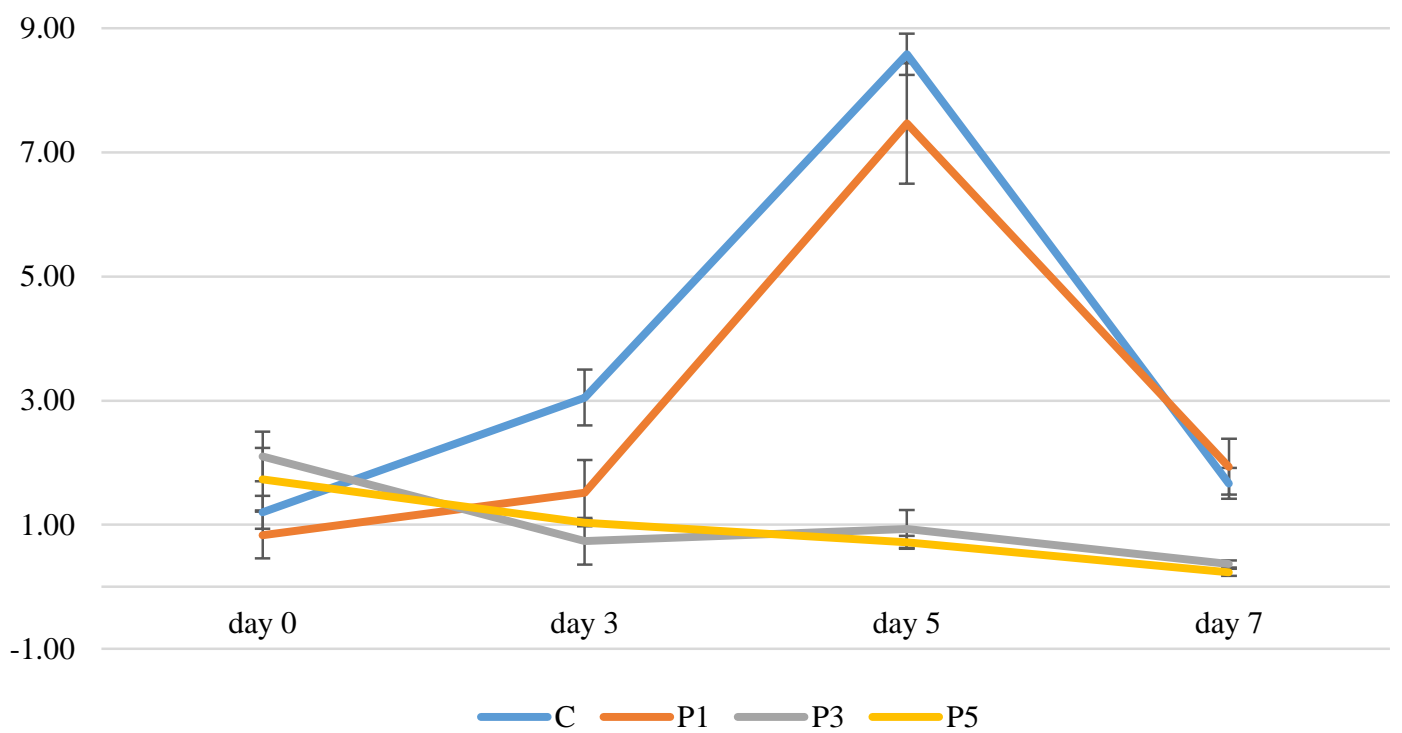

Figure 2. Changes in Peroxide values of model meat emulsion during storage

*C: emulsion formulated with 0\% PSP, P1: emulsion formulated with 1\% PSP, P3: emulsion formulated with 3\% PSP, P5: emulsion formulated with $5 \%$ PSP

TBARs (mgmalonaldehyde/kg)

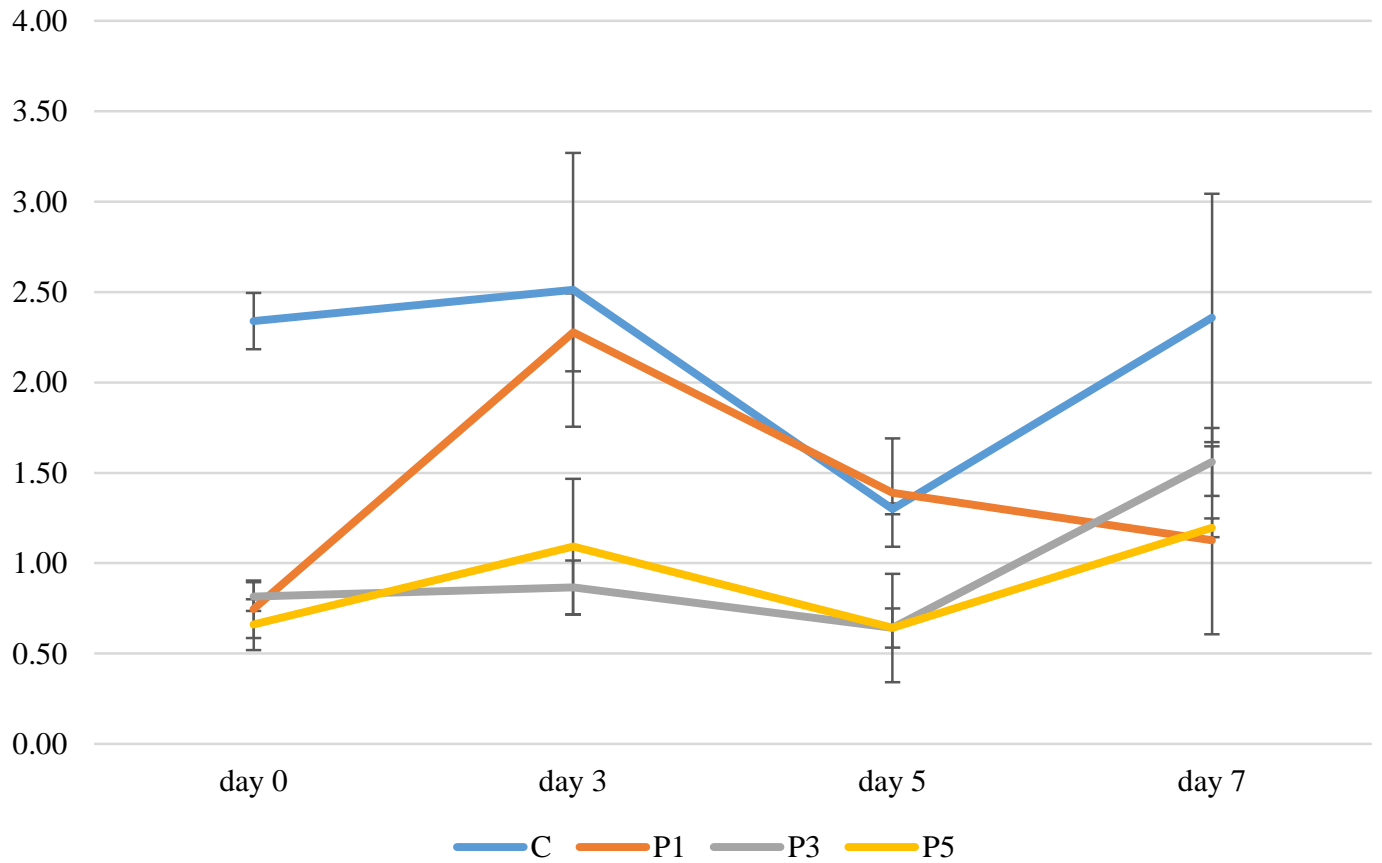

Figure 3. Changes in TBARs values of model meat emulsion during storage

*C: emulsion formulated with 0\% PSP, P1: emulsion formulated with 1\% PSP, P3: emulsion formulated with 3\% PSP, P5: emulsion formulated with $5 \%$ PSP

\section{Lipid oxidation}

Lipid oxidation is one of the most significant factors that reduce the nutritional value, deteriorate quality, and limited the shelf life of meat and meat products containing high unsaturated fatty acids. Processing steps of meat such as grinding and cooking disintegrate the muscle cell membranes and promoting the interaction of lipids with prooxidants such as non-haem iron, accelerating lipid oxidation leading to rapid quality losses (Tichivangana and Morrissey, 1985). The peroxide value indicates the concentrations of peroxides and hydroperoxides that are produced during the early stages of lipid oxidation (Sarabi et al., 2017). The alterations in peroxide values of the emulsions by different concentrations of PSP are given in Figure 2. Initial PV values of $\mathrm{C}, \mathrm{P} 1, \mathrm{P} 3$, and P5 samples were 1.20, 0.83, 2.10, 
and 1.73 meq $\mathrm{O} 2 / \mathrm{kg}$, respectively. Peroxide value was significantly affected by the addition of PSP and storage period $(\mathrm{P}<0.05)$. All peroxide values were lower than 25 meq $\mathrm{O}_{2} / \mathrm{kg}$, which is a limit for fatty food products (Evranuz, 1993). Barimah et al. (2017) concluded that the Taraxacum officinale has great antioxidant potential as well or better than pomegranate juice and PSP. Also, the PV of samples increased during storage.

After the 5th d, the PVs of treatments sharply decreased. This trend was probably sourced from the destruction of hydro-peroxides into secondary oxidation products, particularly aldehydes in the later phase of lipid oxidation. The primary oxidation products are unstable compounds, therefore peroxides and hydroperoxides are divided into volatile products such as aldehydes, ketones, and alcohols (Lee et al., 2010; Uçak, 2020). At the end of the storage period, the lowest PVs were belonging to the P3 (0.36 meq O2/kg) and P5 (0.23 meq O2/kg) treatments. Similar findings were observed by Hazra et al. (2012), Ramchandra (2016), and Qureshi (2017) in different meat products added with pomegranate seed powder. The lowest peroxide values were obtained in trout burgers enriched with pomegranate seed extract at $0.5 \%$ and $1 \%$ levels at the end of the storage (Uçak, 2020).

The thiobarbituric acid reactive substances can also be measured as products of the decompositions of lipid peroxide. TBARs analysis is applied to determine the level of lipid oxidation in meat products and TBARs values of emulsion samples are shown in Figure 3. At d 0 control sample showed the highest TBARs value (2.34 mg $\mathrm{MA} / \mathrm{kg}$ ), while no significant differences between the other samples were reported $(\mathrm{P}<0.05)$. During the storage, TBARs values of all samples increased but with different intensities. TBARs values of control samples had higher values at each evaluation period. Besides that $2 \mathrm{mg} \mathrm{MA} / \mathrm{kg}$ limit value for TBARs (Witte et al., 1970) were not exceed by samples formulated with PSP during whole storage except P1 on day 3. The effect of using PSP in emulsion samples on TBARs values was found to be statistically significant $(\mathrm{P}<0.05)$. The highest $\mathrm{TBARs}$ value $(2.51 \mathrm{mg}$ $\mathrm{MA} / \mathrm{kg}$ ) was recorded in control samples, while P3 and P5 treatments had the lowest TBARs value $(0.64 \mathrm{mg} \mathrm{MA} / \mathrm{kg})$ $(\mathrm{P}<0.05)$. $\mathrm{P} 1$ treatments showed a sharp increase on the 3rd $\mathrm{d}$ of storage $(\mathrm{P}<0.05)$. The increase in TBARs values during storage could be explained by the oxidation of meat lipid. These results agreed with the findings of Debnath et al. (2020) in pork sausage and Naveena et al. (2008) in cooked chicken patties, Devatkal and Naveena (2010) in goat meat. Uçak (2020) found that oxidative changes were delayed and shelf life increased $9 \mathrm{~d}$ in fish burgers enriched with pomegranate seed extract. On 7 th d storage, the highest concentration of TBARs value $(2.36 \mathrm{mg} \mathrm{MA} / \mathrm{kg}$ sample) was recorded in $\mathrm{C}$ samples $(\mathrm{P}<0.05)$. TBARs values were considerably lower in P3 and P5 samples than
$\mathrm{C}$ and $\mathrm{P} 2$ samples throughout the storage period $(\mathrm{P}<0.05)$. According to the results of Naveena et al. (2008), pomegranate peel powder inhibited lipid oxidation to a much greater extent than BHT. This situation may be associated with the fact that pomegranate seed powder is rich in phenolic compounds. Pomegranate seeds may contain total phenolic substances up to $73 \mathrm{mg} / \mathrm{g}$ (Derakhshan et al., 2018), also mean total tannin, flavonoid, and anthocyanin contents of pomegranate seed were reported as $29.85 \mu \mathrm{g}$ tannic acid equivalent/mg extract, $15.82 \mu \mathrm{g}$ quercetin equivalent/mg extract and $0.266 \mu \mathrm{g} \cdot 10-2$ Cy-3 gluc/mg extract (Orak et al., 2012). Results showed that PSP at levels of $3 \%$ and 5\% exhibited antioxidant properties capable of retarding lipid oxidation in cooked chicken meat emulsion samples.

Devatkal et al. (2010) used pomegranate peel, pomegranate seed, and kinnow peel powder extracts in goat meat. They reported that the lowest TBARs value in the samples formulated with pomegranate peel powder and the highest DPPH value in the samples containing pomegranate seed powder.

\section{Color}

Changes in the cross-sectional color of treatments are exhibited in Table 4. $L^{*}, a^{*}$, and $b^{*}$ of treatments is between 65.25-68.29, 1.75-3.23, and 10.16-16.84 respectively. The addition of PSP led to significant differences in all the color parameters $(\mathrm{P}<0.05)$. The lowest $L^{*}$ (lightness) value was observed in $\mathrm{P} 1$ compared with the other groups $(\mathrm{P}<0.05)$. The decrease in the $L^{*}$ value might be attributed to the color of PSP which is light brown. Anthocyanins have a significant role in the color of the pomegranate seeds (Legua et al., 2000). Yellowness $\left(b^{*}\right)$ values of emulsions showed a decreasing incorporating with PSP.The present findings agreed with the results of El-Gharably and Ashoush (2011), who reported a decrease in $b^{*}$ values of beef sausages added with beetroot powder or pomegranate peel powder and beetroot powder mixture. Devatkal et al. (2010) also reported decreased color parameters $\left(L^{*}, a^{*}\right.$ and $\left.b^{*}\right)$ in goat patties containing pomegranate rind and seed powder extracts. $a^{*}$ values of samples decreased with the addition of $3 \%$ and $\% 5$ PSP, on the other hand, there is no change between control and P1 groups. P1 samples had a similar redness value with $\mathrm{C}$ samples. Similar to our findings Al-Juhaimi et al. (2016) reported that the use of moringa seed flour in beef burger formulation decreased $a^{*}$ values. The changes recorded in color parameters could be possibly derived from the high amount of myoglobin that exists in the control treatment and the color of PSP. Pomegranate juice and peel powder chicken patties resulted in lower $a^{*}$ values (Naveena et al., 2008). Decreased ' $L^{*}$ ', ' $a *$ ' and ' $b^{*}$ ' values reported for goat meat marinated in a solution contained $4 \%$ PSP (Narsaiah et al., 2011).

Table 4. Color parameters of model meat emulsion formulated with PSP

\begin{tabular}{llcc}
\multicolumn{2}{c}{ Treatments } & \multicolumn{2}{c}{ Color parameters } \\
\hline C & $L^{*}$ & $a^{*}$ & $16.84 \pm 0.29^{\mathrm{a}}$ \\
P1 & $68.29 \pm 0.54^{\mathrm{a}}$ & $3.17 \pm 0.40^{\mathrm{a}}$ & $14.68 \pm 0.44^{\mathrm{b}}$ \\
P3 & $65.25 \pm 1.11^{\mathrm{b}}$ & $3.23 \pm 0.34^{\mathrm{a}}$ & $11.13 \pm 1.00^{\mathrm{c}}$ \\
P5 & $67.95 \pm 0.64^{\mathrm{ab}}$ & $1.75 \pm 0.53^{\mathrm{b}}$ & $10.16 \pm 0.35^{\mathrm{c}}$
\end{tabular}

Mean values \pm standard deviation, ${ }^{\text {a-c }}$ : different letters in the same column means significant differences $(\mathrm{P}<0.05)$. 


\section{Conclusion}

In conclusion, it has been observed that the incorporation of pomegranate seed powder is a compatible enrichment strategy of the chicken meat emulsion formulation. Enrichment of chicken meat emulsion with different levels of pomegranate seed powder resulted in improved technological properties such as water holding capacity, emulsion stability, and cooking yield. Pomegranate seed powder was able to retard the oxidative changes due to its composition. As a conclusion, it was seen that PSP could have the potential to be a functional ingredient in meat product formulations as both dietary fiber source and antioxidant.

\section{Conflict of interest}

The authors declared that this research has no conflict of interest with any organization.

\section{Author contribution:}

Conceptualization: Serdaroğlu M.

Formal analysis: Yüncü Ö. Sharefiabadi E. Seyedhosseini S.

Methodology: Serdaroğlu M.

Writing - original draft: Serdaroğlu M. Yüncü Ö. Kavuşan HS.

Writing - review \& editing: Serdaroğlu M. Yüncü Ö. Kavuşan HS.

\section{Ethics Approval}

This article does not require IRB/IACUC approval because there are no human and animal participants.

\section{References}

Alakali JS, Irtwange SV, Mzer MT. 2010. Quality evaluation of beef patties formulated with bambara groundnut (Vigna subterranean L.) seed flour. Meat Sci. 85(2):215-223.

Al-Juhaimi F, Ghafoor K, Hawashin MD, Alsawmahi ON, Babiker EE. 2016. Effects of different levels of Moringa (Moringa oleifera) seed flour on quality attributes of beef burgers. CyTA - J of Food. 14(1):1-9.

Anar Ş. 2017. Et ve Et Ürünleri Teknolojisi, Dora Basım-Yayın, 4.Bask1, Bursa, Turkey. ISBN 978-975-2447-24-0.

Anderson JW, Baird P, Davis RH, Ferreri JS, Knudtson M, Koraym A, Waters V, Williams CL. 2009. Health benefits of dietary fiber. Nutr Rev. 67(4):188-205.

AOAC, 2007. Official Methods of Analysis. $17^{\text {th }}$ ed. Association of Official Analytical Chemists International, Arlington, VA. ISBN: 09355847819780935584783

Barimah J, Yanney P, Laryea D, Quarcoo C. 2017. Effect of drying methods on phytochemicals, antioxidant activity and total phenolic content of dandelion leaves. Am J Food Nutr. 5(4):136-141.

Cava R, Ladero L, Cantero V, Ramirez MR. 2012. Assessment of different dietary fibers (tomato fiber, beetroot fiber, and inulin) for the manufacture of chopped cooked chicken products. J Food Sci. 77(4):2-8.

Cofrades S, Lopez-Lopez I, Solas MT, Bravo L, JimenezColmenero F. 2008. Influence of different types and proportions of added edible seaweeds on characteristics of low-salt gel/emulsion meat systems. Meat Sci. 79: 767-776.
Debnath K, Hazarika P, Das H, Chaudhary JK, Das A, Kumar S, Rahaman S, Nath S. 2020. A study on pork sausage incorporated with olive oil, dried apple pulp powder and pomegranate seed powder. J Entomol Zool. 8(5): 2119-2123.

Derakhshan Z, Ferrante M, Tadi M, Ansari F, Heydari A, Hosseini MS, Conti GO, Sadrabad EK. 2018. Antioxidant activity and total phenolic content of ethanolic extract of pomegranate peels, juice and seeds. Food Chem Toxicol. 114:108-111.

Devatkal S, Manjunatha M, Thorat P. 2014. Effect of vacuum packaging and pomegranate peel extract on quality aspects of ground goat meat and nuggets. J Food Sci Technol. 51:26852691.

Devatkal SK, Narsaiah K, Borah A. 2010. Anti-oxidant effect of extracts of kinnow rind, pomegranate rind and seed powders in cooked goat meat patties. Meat Sci. 85:155-159.

Devatkal SK, Naveena BM. 2010. Effect of salt, kinnow and pomegranate fruit by-product powders on color and oxidative stability of raw ground goat meat during refrigerated storage. Meat Sci. 85:306-311.

Ebrahiem MA, Kafi SH, Twfiq SA, Jadalla JB, Tibin MAM, Bukhari SAS, Dahia BH. 2020. Effect of Adding Cowpea Seed Powder on Physiochemical Properties and Sensory Evaluation of Fresh Beef Sausage. IJVSMD.1(1):1-6.

Eim VS, Simal S, Rossello C, Femenia A. 2008. Effects of addition of carrot dietary fibre on the ripening process of a dry fermented sausage (sobrassada). Meat Sci. 80(2):173182.

Ekici L, Ercoşkun H. 2007. Et ürünlerinde diyet lif kullanımı. Gida Teknolojileri Elektronik Dergisi.1:83-90.

El - Gharably, Alia AM, Ashoush IS. 2011. Utilization impact of adding pomegranate rind powder and red beet powder as natural antioxidant on quality characteristics of beef sausage. World J Dairy \& Food Sci. 6(1):86-97.

Eltilib H, Elgasim EA, Mohamed Ahmed IA. 2016. Effect of incorporation of Cyperus rotundus $L$. rhizome powder on quality attributes of minced beef meat. J Food Sci Technol. 53(9): 3446-3454.

Evranuz, E. Ö.1993. The effects of temperature and moisture content on lipid peroxidation during storage of unblanched salted roasted peanuts: shelf life studies for unblanched salted roasted peanuts. Int. J Food Sci and Technol. 28(2):193-199.

Fernandez-Lopez J, Sendra-Nadal E, Navarro C, Sayas E, ViudaMartos M, Perez-Alvarez JA. 2009. Storage stability of a high dietary fibre powder from orange by-products. Int. J Food Sci and Technol. 44:748-756.

Flynn AW, Bramblett VD. 1975. Effects of frozen storage cooking method and muscle quality and attributes of pork loins. J Food Sci. 40:631-633.

Garrido-Cruz JL, Muñoz RS, Rodríguez-Huezo ME.2020.Physicochemical and sensory characterization of a functional meat product added with pomegranate peel flour. Nacameh. 14(2):61-77.

Gil MI, Tomas-Barberan FA, Hess-Pierce B, Holcroft DM, Kader AA.2000. Antioxidant activity of pomegranate juice and its relationship with phenolic composition and processing. J Agri Food Chem. 48(10):4581-4589.

Gölükcü, M., Tokgöz, H., Kıralan, M. 2008. Ülkemizde yetiştirilen önemli nar (Punica granatum) çeşitlerine ait çekirdeklerin bazı özellikleri. Gıda, 33(6), 281-290.

Grossi A, Søltoft-Jensen J, Knudsen JC, Christensen M, Orlien V. 2011. Synergistic cooperation of high pressure and carrot dietary fibre on texture and colour of pork sausages. Meat Sci. 89(2):195-201.

Gül H, Şen H. 2017. Effects of pomegranate seed flour on dough rheology and bread quality. CyTA - Journal of Food. 15(4): 622-628. 
Gullón P, Gonzalo A, Gullón B, Tomasevic I, Lorenzo JM.2020. Pomegranate peel as suitable source of high-added value bioactives: tailored functionalized meat products. Molecules. 25(12), 2859.

Hazra S, Biswas S, Bhattacharya D, Das SK, Khan A.2012. Quality of cooked ground buffalo meat treated with crude extract of Moringa oleiferia (Lam.) leaves. J Food Sci Technol. 49:240-245.

Hughes E, Cofrades S, Troy DJ. 1997. Effects of fat level, oat fibre and carrageenan on frankfurters formulated with 5, 12 and 30\% fat. Meat Sci. 45:273-281.

Jalal H, Pal MA, Ahmad SR, Rather M, Andrabi M, Hamdani S. 2018. Physico-chemical and functional properties of pomegranate peel and seed powder. TPI. 7(4): 1127-1131.

Jimenez-Colmenero F, Delgado-Pando G. 2013. Fiber-enriched meat products (Ed. DElcour, D.A., Poutanen, K), Woodhead Publishing, Cambridge, UK.

Kaur S, Kumar S, Bhat SF. 2015. Utilization of pomegranate seed powder and tomato powder in the development of fiberenriched chicken nuggets. Nutr Food Sci. 45(5): 793-807.

Kim YK. 2020. Quality Improvement of the chicken sausage with pepper seed (Capsicum annuum L.). Curr Res Nutr Food Sci. 8(3):829-836.

Koniecko R. 1979. In: Handbook for meat chemists. Avery Publishing Group. Inc. Wayne. New Jersy. 53-55.

Kumar D, Mehta N, Chatli MK, Malav OP, Kumar P.2019. Quality attributes of functional pork patties incorporated with kinnow (Citrus reticulata) pomace powder. J Anim Res. 9(3): 411-417.

Kurt, Ş. 2017. Investigation of the potential usage of pomegranate seed flour in the beef patties. ADYUSCI. 7(1):1-11.

Lee JA, Kim GW, Kim HY, Choe J. 2019. Influences of Red Pepper Seed Powder on the Physicochemical Properties of a Meat Emulsion Model System. Food Sci Anim Resour. 39(2):286-295.

Lee MA, Choi JH, Choi YS, Han DJ, Kim HY, Shim SY, Chung HK, Kim CJ. 2010. The antioxidative properties of mustard leaf (Brassica juncea) kimchi extracts on refrigerated raw ground pork meat against lipid oxidation. Meat Sci. 84(3):498-504.

Lee MA, Han DJ, Jeong JY, Choi JH, Choi YS, Kim HY, Paik, HD, Kim CJ. 2008. Effect of kimchi powder level and drying methods on quality characteristics of breakfast sausage. Meat Sci. 80: 708-714.

Legua P, Melgarejo P, Martínez M, Hernández F. 2000. Evolution of anthociyanin content of four pomegranate cultivars (Punica granatum L.) during fruit development. Options Méditerranéennes. Série A, Séminaires Méditerranéens n. 42: CIHEAM, Madrid: 93-97.

Li Y, Guo C, Yang J, Wei J, Xu J, Cheng S. 2006. Evaluation of antioxidant properties of pomegranate peel extract in comparison with pomegranate pulp extract. Food Chem. 96: 254-260.

Lin MJY, Humbert, ES, Sosulski FW. 1974. Certain functional properties of sunflower meal products. J Food Sci. 39(2): 368370.

McConnell AA, Eastwood MA, Mitchell WD. 1974. Physical characteristics of vegetable foodstuffs that could influence bowel function. J Sci Food Agric. 25: 1457-1464.

Murphy EW, Criner PE, Grey BC. 1975. Comparison of methods for calculating retentions of nutrients in cooked foods. J Agric Food Chem. 23:1153-1157.

Narsaiah K, Jha NS, Devatkal SK, Borah A, Singh DB, Sahoo J. 2011. Tenderizing effect of blade tenderizer and pomegranate fruit products in goat meat. J Food Sci Technol. 48(1): 61-68.

Naveena BM, Sen AR, Vaithiyanathan S, Babji Y, Kondaiah N. 2008. Comparative efficacy of pomegranate juice, pomegranate rind powder extract and BHT as antioxidants in cooked chicken patties. Meat Sci. 80:1304-1308.
Okumuş G. 2016. Nar (Punica Granatum L.) Kabuk ve çekirdeklerinin antioksidan kapasitelerinin belirlenmesi. Msc. thesis, Uludağ University, Bursa, Turkey.

Orak HH, Yagar H, İşbilir SS. 2012. Comparison of antioxidant activities of juice, peel, and seed of pomegranate (Punica granatum L.) and inter-relationships with total phenolic, Tannin, anthocyanin, and flavonoid contents. Food Sci. Biotechnol. 21(2): 373-387.

Öztürk B, Serdaroğlu M, Karabıyıkoğlu M. 2017. Stability of model system beef emulsions containing linseed oil-in-water gelled emulsions. $63^{\text {rd }}$ International Congress of Meat Science and Technology. Netherlands.

Öztürk, B., Serdaroğlu, M. 2018. Effects of jerusalem artichoke powder and sodium carbonate as phosphate replacers on the quality characteristics of emulsified chicken meatballs. Korean journal for food science of animal resources, 38(1), 26.

Petracci M, Bianchi M, Mudalal S, Cavani C. 2013. Functional ingredients for poultry meat products. Trends Food Sci Technol. 33(1): 27-39.

Purma-Adıbelli Ç, Serdaroğlu M. 2017. Quality characteristics of frankfurters formulated with apricot pomace obtained from apricot juice processing. TURJAF. 5(3):281-288.

Qureshi AI.2017. Development of fenugreek spent hen meat patties via incorporation of fenugreek seed powder and its extract. MSc. thesis, Faculty of Veterinary Sciences and Animal Husbandry, Sher-e-Kashmir University of Agricultural Sciences and Technology, Kashmir, India.

Ramchandra YS. 2016. Assessment of quality of chicken nuggets treated with garlic extract at refrigerated storage. MSc. thesis, Bombay Veterinary College, Mumbai, India.

Sajad S, Ahmad SR, Irshad S, Qureshi A, Fayaz A, Mehraj F, Jalal H. 2020. Influence of the aqueous extract of dandelion (Taraxacum officinale) powder on the quality of chicken meat loaves. J Entomol Zool Stud. 8(4): 1579-1582.

Sánchez-Zapata E, Muñoz CM, Fuentes E, Fernández-López J, Sendra E, Sayas E, Navarro C, Pérez-Alvarez JA. 2010. Effect of tiger nut fibre on quality characteristics of pork burger. Meat Sci. 85(1):70-76.

Santhi D, Kalaikannan A, Natarajan A. 2020. Characteristics and composition of emulsion-based functional low-fat chicken meatballs fortified with dietary fiber sources. J Food Process Eng. 43:3-12.

Sarabi M, Keramat J, Kadivar M. 2017. Antioxidant effect of rosemary extract and BHT on the quality of coated fried Escolar (Lipidocybium flavobrunium) fish fillets during frozen storage. Int Food Res J. 24(2): 525-533. International

Sayago-Ayerdi SG, Brenes A, Goni I. 2009. Effect of grape antioxidant dietary fiber on the lipid oxidation of raw and cooked chicken hamburgers. LWT- Food Sci Technol. 42(5):971-976.

Serdaroğlu M, Kavuşan HS, İpek G, Öztürk B. 2018. Evaluation of the quality of beef patties formulated with dried pumpkin pulp and seed. Korean J Food Sci An. 38(1):1-13.

Sharma P, Yadav S. 2020. Effect of incorporation of pomegranate peel and bagasse powder and their extracts on quality characteristics of chicken meat patties. Food Sci Anim Resour. 40(3):388-400.

Smaoui S, Hlima HB, Mtibaa AC, Fourati M, Sellem I, Elhadef K, Ennouri K, Mellouli L. 2019. Pomegranate peel as phenolic compounds source: Advanced analytical strategies and practical use in meat products. Meat Sci. 158:107914.

Taner B, Özge T. 2018. Gıda ve beslenme açısından nar, nar ürünleri ve üretimi, Nar Sağlıkta Yıldız, Gece Kitaplığı, 1.Bask1, ISBN: 978-605-288-346-4.

Tichivangana JZ, Morrissey PA.1985. The influence of $\mathrm{pH}$ on lipid oxidation in cooked meats from several species. IR J Food Sci Technol. 9:99-106. 
Turgut SS, Ișıkçı F, Soyer A. 2017. Antioxidant activity of pomegranate peel extract on lipid and protein oxidation in beef meatballs during frozen storage. Meat Sci. 129:111-119.

Uçak İ. 2020. Nar çekirdeği ekstraktı ile zenginleştirilmiş balık burgerlerin oksidatif, mikrobiyal ve duyusal kalite değişimlerinin incelenmesi. Food and Health. 6(4):238-247.

Verma AK, Sharma BD, Banerjee R. 2010. Effect of sodium chloride replacement and apple pulp inclusion on the physicochemical, textural and sensory properties of low fat chicken nuggets. LWT - Food Sci Technol. 43:715-719.
Viuda-Martos M, Ruiz-Navajas Y, Martin-Sánchez A, SánchezZapata E, Fernández-López J, Sendra E, Sayas-Barberá E, Navarro C, Pérez-Álvarez JA. 2012. Chemical, physicochemical and functional properties of pomegranate (Punica granatum L.) bagasses powder co-product. J Food Eng. 110(2):220-224

Witte VC, Krauze GF, Bailey ME. 1970. A new extraction method for determining 2-thiobarbituric acid values of pork and beef during storage, J Food Sci. 35(5): 582-585.

Zago GR, Gottardo FM, Bilibio D, Freitas CP, Bertol CD, Dickel EL, dos Santos RL. 2020. Pomegranate (Punica granatum L.) peel lyophilized extract delays lipid oxidation in tuscan sausages. Cienc. Rural. 50(4): e20190689. 